\title{
Development of Interest Recommendation Analysis Application
}

\author{
Ericha Sholeha ${ }^{1, *}$ Endang P. Sartinah ${ }^{1}$ Najlatun Naqiyah ${ }^{1}$
}

\author{
${ }^{1}$ Universitas Negeri Surabaya \\ ${ }^{*}$ Corresponding author. Email: ericha.19010@mhs.unesa.ac.id
}

\begin{abstract}
Until this time, counsellors in junior high school had used Microsoft excel to help make interest recommendations. Thus, counsellors needed eight weeks to analyze some data to produce interest recommendations. This research aims to produce an application that can assist counsellors in saving data, analyzing data, and producing interest recommendations according to guidance and counselling operational guidelines at junior high school 2016. The application was developed is Aplikasi Analisis Peminatan (AAP). It was developed using research and development procedures, according to Borg and Gall. Through the stages of research and information collecting, planning, developing a preliminary form of product, preliminary field testing, and primary product revision. Data collection used a feasibility questionnaire. Data analysis used a percentage formula. The results of data analysis showed that AAP has $95,72 \%$ feasibility to save data, analyze some data to make interest recommendations. AAP can be used by counsellors to save time when making interest recommendations.
\end{abstract}

Keywords: Interest, Recommendation, Application.

\section{INTRODUCTION}

In order to help the students to understand their interests to determine their secondary schools, the counsellor is organizing assessments to identify abilities, talents, interests, and students' career tendencies [1]. The assessment results can be the basis for considering students' self to analyze their strengths and weaknesses and make decisions to choose and plan their secondary school [2]. At the end of junior high school, the counsellor also must make interest recommendation letters for all their students [1].

Interest recommendation letters are given to all students in grade IX who are declared a graduate to give some information about students who can be considered to choose the secondary school [1]. The recommendation letters, which accordance with operational guidance and counselling guidelines at junior high school 2016, will be made with some data for consideration. The data are (1) academic achievements in grades VII, VIII, and IX; (2) nonacademic achievements from elementary school to junior high school; (3) results of possible psychological detection (IQ, talents, interests, personality (if any)); (4) student's interest, that was showed from the interesting instrument which developed by a counsellor or relevant institutions; (5) junior high school national exam scores; and (6) parents expectation, that was showed from parental expectation questionnaire which developed by the counsellor.

Based on interview results with counsellors at Junior High School of 32 Surabaya and Junior High School of 48 Surabaya about the process to make interest recommendation letters. The results showed that counsellors used an interest recommendation application based on Microsoft excel in making interest recommendation letters. This application could help counsellors in saving some data to make interest recommendation letters. Then, counsellors must analyze some data manually to decide interest recommendations for students. Counsellors need about eight weeks to make interest recommendation letters for all students in IX grade. So, the main task is that counsellors will be busy with administrative activities and cannot provide responsive services (counselling). This is contrary to the opinion that counsellors main task is to provide guidance and counselling services, not administration [3].

The amount of time needed to make interest recommendation letters and many services must be provided to students, so counsellors at Junior High 
School of 32 Surabaya and Junior High School of 48 Surabaya cannot make interest recommendation letters for all students in IX grade. Of course, this is inconsistent with the basic principle of guidance and counselling implementation that guidance and counselling services are attended for all students using various strategies (personal development and support system)[4]. This research would develop an interest recommendation analysis application to give a support system for counsellors.

The interest recommendation analysis application is expected to help the counsellor's performance in making an interest recommendation letter that is ready to print. The interest recommendation analysis application is a web-based application. This application is operated offline, can be operated on a PC or laptop, with the following criteria: (1) minimum operating system using Windows 7, (2) minimum RAM is 1 GB.

\section{METHOD}

This research used research and development methods, according to Borg and Gall [5]. The research subjects consisted of a material expert, a media expert, and two counsellors who are counsellors coordinators at Junior High School of 32 Surabaya and Junior High School of 48 Surabaya. The data collection technique used a questionnaire that used feasibility questionnaire as an instrument. The following is an explanation of each stage in this research procedure:

\subsection{Research And Information Collecting}

Things had to do at this stage include: (a) Collected data about need assessment, through spread students need questionnaire called Angket Kebutuhan Peserta Didik (AKPD) to students in IX grade at Junior High School of 32 Surabaya and Junior High School of 48 Surabaya; (b) Analyzed the data results of students need a questionnaire which had been filled; (c) Interviewed counsellors at Junior High Schoool of 32 Surabaya and Junior High School of 48 Surabaya about implementation guidance career services and individual career plans, and the obstacle to did the service; (d) Interviewed counsellors about support system which were used to maximize in implementation guidance career services and individual career plans; (e) Analyzed the counsellors' interview results.

\subsection{Planning}

Things had to do at this stage include (a) Determined support system which can help counsellors to implement guidance career services and individual career plans based on facilities and counsellors competencies in technology utilization; (b) Determined the goals of product development; (c) Determined validation subjects and product trial subjects. Validation subjects are material experts and media experts. Material expert is a lecturer in guidance and counselling with minimum education essential is master degree in guidance and counselling. Media expert is a lecturer in educational technology with at least hold a master degree in educational technology. Product trial subjects are counsellors with at least hold a bachelor's degree in guidance and counselling; (d) Developed the instrument to evaluate the feasibility product.

\subsection{Develop Preliminary Form Of Product}

In this stage had to the developed product was in prototype form. The prototype product which according to the goals of the product development. The prototype was assumed could be used for counsellors in implementation guidance career services and individual career plans, significantly helping counsellors to make interest recommendations.

\subsection{Preliminary Field Testing}

Things had to do at this stage include: (a) Tested the prototype product to expert material and expert media for knowing feasibility in materiality and utility media used feasibility instrument for material expert and feasibility instrument for media expert; (b) Analyzed the data results from the expert material test and expert media test used percentage formula; (c) interpreted the feasibility scores from expert materials test and expert media test; (d) Tried the prototype product to counsellors for knowing helpfulness and efficiency of the product to help counsellors performance when making interest recommendation. This step used a feasibility instrument for counsellors; (e) Analyzed the data results from product trials using percentage formula; (f) interpreted the feasibility scores from product trials.

Here is the percentage formula [6]:

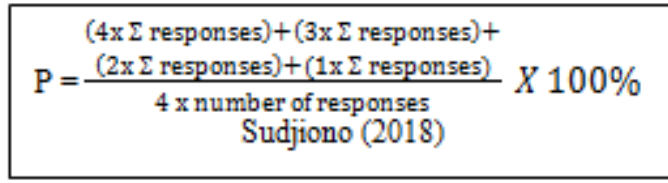

Interpreted the calculated score with the following feasibility criteria [7]:

Table 1. Product feasibility criteria

\begin{tabular}{|l|l|l|}
\hline Value Range & Description & Conversion \\
\hline $86 \%-100 \%$ & Very good & A \\
\hline $72 \%-85 \%$ & Pretty Good & B \\
\hline $58 \%-71 \%$ & Good & C \\
\hline $44 \%-57 \%$ & Poorly good & D \\
\hline $0 \%-43 \%$ & Not good & E \\
\hline
\end{tabular}




\subsection{Main Product Revision}

This stage would be revised the product to get the perfect product based on material expert suggestion, media expert suggestion, and product trial subjects (counsellors).

\section{RESULTS AND DISCUSSION}

\subsection{Results}

The analysis of students needs assessment showed that $19 \%$ of 398 students in IX grade at Junior High School of 32 Surabaya had yet to choose the secondary school at senior high school or vocational high school. $16 \%$ of the students had yet identified their interest, and $3 \%$ had different opinions with their parents in determining their secondary school. While, $17 \%$ of 421 students in IX grade at Junior High School of 48 Surabaya had yet chosen secondary school at senior high school or vocational high school, because of $12 \%$ students not identified their interest tendencies and 5\% students had variation opinion with their parents in determining their secondary school.

The results of interviews with counsellors at Junior High School of 32 Surabaya and Junior High School of 48 Surabaya showed that guidance career services and individual career plans implemented through guidance curriculum, individual planning, and responsive service (individual counselling and group counselling). However, there were some obstacles in the implementation, especially in making interest recommendations to help students identify their potencies and interests. Counsellors needed a support system that could be done using computer technology to analyze some data to make interesting recommendations. Counsellors hope that the interest recommendation produced from the application will be made according to guidance and counselling implementation guidelines at junior high school 2016.

Then, collect the information about interest recommendation format according to guidance and counselling implementation guidelines at junior high school 2016. According to guidance and counselling implementation guidelines at junior high school 2016, the interest recommendation was arranged based on the following data; (a) Academic achievements in grades VII, VIII, and IX; (b) Non-academic achievements from elementary school to junior high school; (c) Results of possible psychological detection (IQ, talents, interests, personality (if any)); (d) Student's interest that was showed from the interesting instrument which developed by a counsellor or relevant institutions; (e) Junior high school national exam scores; and (f) Parents expectation that was showed from parental expectation questionnaire which developed by the counsellor. Interest recommendation letters are given to all students in grade IX who are declared graduates to give some information about students who can be considered to choose the secondary school (Suryapranata et al., 2016). However, this year the students at junior high school national exam did not do. So, the junior high school national exam scores do not fill the application.

Based on the information collected, a computer application would be developed to help counsellors save data, analyze data to make interest recommendations, and produce interest recommendation letters according to guidance and counselling implementation guidelines at junior high school 2016. The application could load the following data: (a) Students identity; (b) Academic achievements in grades VII, VIII, and IX; (c) Nonacademic achievements from elementary school to junior high school; (d) Results of IQ test; (e) Results of interest test; (f) Parents expectation, that was showed from parental expectation questionnaire which developed by the counsellor. The application was named Aplikasi Analisis Peminatan (AAP).

The validation product was done by a material expert and a guidance and counselling expert; both were doctors in their field. Product trial was done by counsellors coordinator at Junior High School of 32 Surabaya and Junior High School of 48 Surabaya. This research used the feasibility instrument, which was developed according to feasibility indicators based on Weston [8].

Product validation test by a material expert about the accuracy of application concept got $90,38 \%$, which means AAP is a perfect application and according to guidance and counselling implementation guidelines at junior high school 2016. Product validation test by media expert about the display, easy navigation, and the language in the application got $100 \%$, which means AAP is a very decent application because it had a simple display, is easy to navigate, and words in the application were understandable. Product trials by counsellors about usefulness and efficiency in making interest recommendations got 96,25\%, which means AAP was a useful application to help counsellors in making interest recommendations at a shorter time than used application based on Microsoft excel.

\subsection{Discussion}

AAP had an advantage in more function to analyze data AAP than application based on Microsoft excel. The data input in the AAP will be analyzed automatically. So that counsellors did not need to analyze data manually to make interest recommendations. AAP could produce interest recommendation letters that are all ready to print; its format is according to guidance and counselling implementation guidelines at junior high school 2016. Used AAP, a counsellor at Junior High Schools of 48 
Surabaya could make interest recommendation letters for all students in IX grade in four weeks. At the same time, the counsellor at Junior High Schools of 32 Surabaya could make interest recommendation letters for all students in IX grade in three weeks.

The application based on Microsoft excel had two categories of interest recommendation, those are naturally scientific and social science. In comparison, AAP had six categories of interest recommendation, religious sciences, arts, natural sciences, social sciences, and linguistics. Six categories in AAP would make accessible to help students identify their interests, potencies, and ability to determine secondary school (senior high school, vocational high schools, and religion-based school).

\section{CONCLUSION}

This research and development through research and collecting information, planning, develop a preliminary form of product, preliminary field testing, primary product revision. Validation test subjects were material experts and media experts. Product trial subjects were two counsellors from Junior High School of 32 Surabaya and Junior High School of 48 Surabaya. The validation test and product trial used the feasibility instrument, which was developed according to Weston [8]. There were three instruments: feasibility questionnaire for material expert, feasibility questionnaire for media expert, and feasibility questionnaire for users (counsellors).

Through the procedures, the validation test results by the material expert showed that AAP was an excellent application and developed according to guidance and counselling implementation guidelines at junior high school 2016. The validation test results by the media expert showed that AAP was a very decent application because it had a simple display, was easy to navigate, and the words in the application were understandable. The results of the product trial by counsellors showed that AAP was helpful application to help counsellors in making interest recommendation at shorter time than used application based on microsoft excel.

\section{AUTHORS' CONTRIBUTIONS}

Authors collaborated to carry out this research and development. Ericha Sholeha contributed to product development ideas and carried out research and development procedures. Endang Pudjiastuti Sartinah and Najlatun Naqiyah contributed to directing the products developed in accordance with the operational guidelines of the implementation of guidance and counseling in junior high schools 2016.

\section{ACKNOWLEDGMENTS}

I would like to express my gratitude to: (a) counselors at SMP Negeri 32 Surabaya and SMP Negeri 32 Surabaya, (b) Dr. Budi Purwoko, M.Pd. as material expert vaidator, (c) Dr. Fajar Arianto as media expert validator, (d) Principals of SMP Negeri 32 Surabaya and SMP Negeri 48 Surabaya, (e) Director of Postgraduate Guidance and Counseling, Universitas Negeri Surabaya.

\section{REFERENCES}

[1] Suryapranata., S.Yusuf., M. Farozin, Panduan Operasional BK di SMP, Jakarta: Kementrian Pendidikan dan Kebudayaan Republik Indonesia, 2016.

[2] A. Susanto, Bimbingan dan Konseling di Sekolah. Jakarta: Prenadamedia Group, 2018.

[3] Ernawati, "Pengembangan Aplikasi Analisis Peminatan dalam Program Bimbingan dan Konseling untuk Sekolah Lanjutan" Jurnal Bimbingan Konseling dan Dakwah Islam, pp. 4758, 2019. DOI: https://doi.org/10.14421/hisbah. 2019.161-04.

[4] U.Azam, Bimbingan dan Konseling Perkembangan di Sekolah Teori dan Praktik. Yogyakarta: Dee Publish, 2016.

[5] R. W. Borg, and J.P. Gall, Educational Research 7th. Boston Allyn and Bacon, 2003

[6] Arikunto, S. Prosedur Penelitian Suatu Pendekatan Praktik. Jakarta: Rineka Cipta, 2016.

[7] A. Sudjiono, Pengantar Statistik Pendidikan. Jakarta: Indeks, 2018.

[8] C. Weston., L. McAlpine., T. Bordonaro, "A Model for Understanding Formative Evaluation in Instructional Design," Educational Technology Research and Development, pp. 29-48, DOI: https://doi.org/10.1007/BF02300454 